\title{
Agroclimatic zoning of the Brazilian state of Mato Grosso for the production of soybean seeds of early cultivars ${ }^{1}$
}

\author{
Dielle Carmo de Carvalho Neres ${ }^{2 *}$ (DD, Ricardo Santos Silva Amorim ${ }^{3}$ (D), \\ Maria Cristina de Figueiredo e Albuquerque ${ }^{3}$ (D) Gilda Pizzolante de Pádua ${ }^{4}$ (D), \\ José de Barros França-Neto ${ }^{5}$
}

\begin{abstract}
The objective of this work was to carry out the agroclimatic zoning of the Brazilian state of Mato Grosso, in order to identify the regions with the best climatic conditions for producing seeds with high quality of early soybean cultivars. For this purpose, the average monthly temperature data from 11 conventional and 34 automated meteorological stations were used. Due to the low number of stations with data temperature available, this variable was estimated using spatial regression equations, having latitude, longitude and altitude as input variables. Regions with high or low climatic risk were defined according to the average temperatures observed in January and February. The following three categories were established: favorable $\left(\leq 24{ }^{\circ} \mathrm{C}\right)$; moderately favorable $(24.1$ to $25^{\circ} \mathrm{C}$ ) and slightly favorable $\left(\geq 25.1^{\circ} \mathrm{C}\right)$. For the material confection, map usage, and geographical data compilation, the inverse distance squared weighted interpolation method was applied. The ArcGIS system was employed to compose the thematic map, in which the best areas for producing seeds of early soybean cultivar were marked. Most of the Southeastern, and Western regions of Mato Grosso were considered to be favorable for producing high quality seeds of early soybean cultivars (average temperature $\leq 24^{\circ} \mathrm{C}$ ).
\end{abstract}

Index terms: Glycine max, temperature, altitude, ArcGIS.

\section{Zoneamento agroclimático do estado de Mato Grosso para a produção de sementes de soja de cultivares precoces}

\begin{abstract}
RESUMO - O objetivo neste trabalho foi realizar o zoneamento agroclimático, visando identificar as regiões do estado de Mato Grosso com as melhores condições climáticas para a produção de sementes de soja com alta qualidade de cultivares precoces. Para a elaboração desse zoneamento, foram utilizados, inicialmente, dados mensais de temperatura média de 11 estações meteorológicas convencionais e 34 estações meteorológicas automáticas. Devido à baixa densidade de estações com dados de temperatura, esta variável foi estimada por meio de equações de regressão espacial, que tinham como variáveis preditoras a latitude, longitude e altitude. A definição das regiões de maior ou menor risco climático foi associada à ocorrência de temperaturas médias dos meses de janeiro e fevereiro. Foram definidas três classes: favorável $\left(\leq 24{ }^{\circ} \mathrm{C}\right)$; medianamente favorável $(24,1$ a 25 $\left.{ }^{\circ} \mathrm{C}\right)$ e pouco favorável $\left(\geq 25,1^{\circ} \mathrm{C}\right)$. Para elaboração, utilização dos mapas e compilação dos dados geográficos, procedeu-se a interpolação para espacialização, utilizando-se o método do inverso do quadrado da distância. Utilizou-se o sistema ArcGIS, por meio do qual foi confeccionado o mapa temático com as representações das melhores regiões para a produção de sementes de soja de cultivares precoces. A maior parte das regiões Sudeste e Oeste de Mato Grosso é classificada como favorável (temperatura média $\leq 24^{\circ} \mathrm{C}$ ) para a produção de sementes de soja com alta qualidade de cultivares precoces.
\end{abstract}

Termos para indexação: Glycine max, temperatura, altitude, ArcGIS.

\section{Introduction}

Among the factors inherent to agricultural production, climate emerges as the one most capable of limiting the maximum potential productivity (Farias, 2011). Its unpredictability is a major risk factor, which answers for a
${ }^{1}$ Submitted on 09/25/2018. Accepted for publication on 12/18/2018. ${ }^{2}$ Univag Centro Universitário, 78118-900 - Várzea Grande, MT, Brasil,

${ }^{3}$ Universidade Federal de Mato Grosso, 78060-900 - Cuiabá, MT, Brasil.
${ }^{4}$ Embrapa/Epamig, Caixa Postal 311, 38001-970 - Uberaba, MG, Brasil.

${ }^{5}$ Embrapa Soja, Caixa Postal 231, 86001-970 - Londrina, PR, Brasil.

*Corresponding author < dielleneres@gmail.com> 
fairly significant part of the unsuccess of some cultures. Climatic stresses, such as drought, excessive rainfall, extreme temperatures, and insufficient light, not only can drastically reduce crop yields and seed quality, and restrict sites of production, sowing dates and soils where commercially important species can be grown. Thus, they are considered some of the leading causes of seed deterioration in the field (França-Neto et al., 2016).

Soybean seeds are highly sensitive to hot and humid environments during their physiological maturity phase. So, obtaining high-quality seeds can be challenging for most soybean production areas in Brazil, particularly in those located above $24^{\circ} \mathrm{N}$ latitude (Costa et al., 1994). In these locations, the humidity attached to climatic oscillations induces seed deterioration. The effects are magnified in hot weathers, typical of tropical and subtropical regions (Forti et al., 2010).

On account of that, the most viable alternative for producing high-quality soybean seeds under tropical conditions, such as those in the Brazilian state of Mato Grosso, is by cultivating it in sites above $700 \mathrm{~m}$. In these regions, the climate is predominantly dry with mild temperatures during the maturation and harvest stages. It is also possible to adjust the sowing date, so that these events take place in a more favorable environmental condition (França-Neto et al., 2016).

In this sense, a very useful and important instrument is the climatic-risk agricultural zoning, which has been promoted by the Brazilian Ministry of Agriculture for over 20 years (Brasil, 2012; Rodrigues and Rodrigues, 2016). This strategy is included among the national policies for rationalizing the use of natural resources to promote more profitability, stability, and competitiveness in agriculture. In addition it provides farmers the autonomy to identify the suitable planting seasons for cultures in general, also considering the different types of soil and cultivar cycles (Brasil, 2017). Therefore, zoning studies aiming at lowering climate-related risks are of utmost importance to agricultural practices, once they allow producers to allocate their crops to sites where conditions are more favorable to seed production (Pádua et al., 2014).

The climatic-risk zoning uses data to model how climate variability over the years affects the performance of a given culture. It allows inferring, with a sizeable safety margin, the most appropriate place and time for sowing, taking into account differences in the Brazilian regions. In addition, it lists the cultivars that better suit each scenario (Mitidieri and Medeiros, 2008).

In spite of holding one of the highest yields in the country, Mato Grosso has not had climatic zoning directed to soybean seed production performed yet. The climate in the state is often not favorable, which results in high indices of field deterioration. This fact, jointly with injuries caused by stink bugs and mechanical damages, compromises the quality of the seeds in some regions.

For these reasons, the objective of this study was to carry out the agroclimatic zoning of the state, and to identify the regions in Mato Grosso with the best conditions to produce high-quality soybean seeds from early cultivars.

\section{Material and Methods}

The elaboration of the agroclimatic zoning maps initially used the average monthly temperature data $\left(\mathrm{T}_{\text {med }}\right)$ from 11 conventional and 34 automated meteorological stations located in Mato Grosso (Table 1). The selection of these units was based on their spatial distribution over the state. Also, given the scarcity of long-observation series, only stations with at least eight years of monitoring were chosen. All meteorological data used were provided by the Instituto Nacional de Meteorologia [National Institute of Meteorology] (INMET, 2015).

Since there are few meteorological stations with available temperature data in Mato Grosso, it is difficult to elaborate highly accurate maps, containing local variations. Thus, the estimation and spatialization of this variable were performed in order to overcome this setback. Additionally, these procedures allow the obtainment of thermic values in any location, as a function of geographical-dependent parameters - altitude, latitude, and longitude (Cargnelutti Filho et al., 2006; 2008).

The average temperature was estimated and spatialized from latitude, longitude, and altitude inputs, by using spatial regression equations. In this study, multiple regression equations for average monthly temperature entries were used, as proposed by Tarifa (2011). Equations 1 and 2 were applied to January and February, respectively, as these months were deemed to be the period when the final stages of maturation and harvest seeds of early soybean cultivars occur in the state.

$$
\begin{gathered}
\mathrm{Y}=(-0.0062223 * \text { alt })-(0.0168041 * \text { long })+(0.1488236 * \\
\text { lat })+26.10685 \\
\mathrm{Y}=(-0.0057064 * \text { alt })+(0.0343606 \text { * long })+(0.148176 * \\
\text { lat })+22.893694
\end{gathered}
$$

Where: $Y$ is the air average monthly temperature $\left({ }^{\circ} \mathrm{C}\right)$, alt stands for altitude, long for longitude, and lat for latitude.

Prior to the spatial variability and zoning studies, the average temperature in both January and February were estimated by using the databank obtained from selected stations (Table 1). In this assessment, the following parameters were considered: root mean square error (equation 3); Wilmott's index of agreement (equation 4), Nash-Sutcliffe coefficient (equation 5), correlation coefficient and confidence index (equation 6). 
Table 1. Meteorological stations that provided data to build the equations for estimating the average air temperature, with the respective geographical coordinates of the cities in the state of Mato Grosso (INMET, 2015).

\begin{tabular}{|c|c|c|c|c|}
\hline Type & $\begin{array}{c}\text { Meteorological } \\
\text { stations }\end{array}$ & Latitude & Longitude & $\begin{array}{c}\text { Altitude } \\
(\mathrm{m})\end{array}$ \\
\hline Auto & Água Boa & $14^{\circ} 00^{\prime}$ & $52^{\circ} 12^{\prime}$ & 432.0 \\
\hline Auto & Alta Floresta & $09^{\circ} 50^{\prime}$ & $56^{\circ} 06^{\prime}$ & 289.0 \\
\hline Auto & Alto Araguaia & $17^{\circ} 33$ & $53^{\circ} 22^{\prime}$ & 753.0 \\
\hline Auto & Alto Taquari & $17^{\circ} 48^{\prime}$ & $53^{\circ} 17^{\prime}$ & 875.0 \\
\hline Auto & Apiacás & $09^{\circ} 33^{\prime}$ & $57^{\circ} 23$ & 220.0 \\
\hline Auto & Brasnorte & $12^{\circ} 31^{\prime}$ & $58^{\circ} 13^{\prime}$ & 431.0 \\
\hline Auto & Cáceres & $16^{\circ} 02^{\prime}$ & $57^{\circ} 41^{\prime}$ & 116.0 \\
\hline Conv & Cáceres & $16^{\circ} 02^{\prime}$ & $57^{\circ} 41^{\prime}$ & 116.0 \\
\hline Auto & Campo Novo & $13^{\circ} 47^{\prime}$ & $57^{\circ} 50^{\prime}$ & 570.0 \\
\hline Auto & Campo Verde & $15^{\circ} 31^{\prime}$ & $55^{\circ} 08^{\prime}$ & 749.0 \\
\hline Conv & Canarana & $13^{\circ} 47^{\prime}$ & $52^{\circ} 27^{\prime}$ & 430.0 \\
\hline Auto & Carlinda & $10^{\circ} 00^{\prime}$ & $55^{\circ} 47^{\prime}$ & 290.0 \\
\hline Auto & Comodoro & $13^{\circ} 42^{\prime}$ & $59^{\circ} 45^{\prime}$ & 591.0 \\
\hline Auto & Cotriguaçú & $09^{\circ} 54^{\prime}$ & $58^{\circ} 34^{\prime}$ & 261.0 \\
\hline Conv & Cuiabá & $15^{\circ} 37^{\prime}$ & $56^{\circ} 06^{\prime}$ & 151.3 \\
\hline Auto & Cuiabá & $15^{\circ} 37^{\prime}$ & $56^{\circ} 06^{\prime}$ & 151.3 \\
\hline Conv & Diamantino & $14^{\circ} 40^{\prime}$ & $56^{\circ} 45^{\prime}$ & 286.3 \\
\hline Auto & Gaúcha do Norte & $13^{\circ} 11^{\prime}$ & $53^{\circ} 15^{\prime}$ & 379.0 \\
\hline Auto & $\begin{array}{c}\text { Guaratã do } \\
\text { Norte }\end{array}$ & $09^{\circ} 57^{\prime}$ & $54^{\circ} 53^{\prime}$ & 320.0 \\
\hline Conv & Gleba Celeste & $12^{\circ} 28^{\prime}$ & $55^{\circ} 29^{\prime}$ & 415.0 \\
\hline Auto & Guiratinga & $16^{\circ} 20^{\prime}$ & $53^{\circ} 45^{\prime}$ & 526.0 \\
\hline Auto & Itiquira & $17^{\circ} 10^{\prime}$ & $54^{\circ} 30^{\prime}$ & 585.0 \\
\hline Auto & Juara & $11^{\circ} 16^{\prime}$ & $57^{\circ} 31^{\prime}$ & 260.0 \\
\hline Auto & Juína & $11^{\circ} 22^{\prime}$ & $58^{\circ} 43^{\prime}$ & 200.0 \\
\hline Conv & Matupá & $10^{\circ} 25^{\prime}$ & $54^{\circ} 91^{\prime}$ & 285.0 \\
\hline Auto & Nova Ubiratã & $13^{\circ} 24^{\prime}$ & $54^{\circ} 45^{\prime}$ & 518.0 \\
\hline Auto & Novo Mundo & $12^{\circ} 31^{\prime}$ & $58^{\circ} 13^{\prime}$ & 431.0 \\
\hline Conv & Nova Xavantina & $14^{\circ} 70^{\prime}$ & $52^{\circ} 35^{\prime}$ & 316.0 \\
\hline Auto & Paranatinga & $14^{\circ} 25^{\prime}$ & $54^{\circ} 02^{\prime}$ & 474.0 \\
\hline Auto & Pontes Lacerda & $15^{\circ} 15^{\prime}$ & $59^{\circ} 20^{\prime}$ & 256.0 \\
\hline Auto & Porto Estrela & $15^{\circ} 21^{\prime}$ & $57^{\circ} 13^{\prime}$ & 145.0 \\
\hline Conv & Poxoréo & $15^{\circ} 83^{\prime}$ & $54^{\circ} 38^{\prime}$ & 450.0 \\
\hline Auto & Querência & $12^{\circ} 37^{\prime}$ & $52^{\circ} 13^{\prime}$ & 382.0 \\
\hline Conv & Rondonópolis & $16^{\circ} 27^{\prime}$ & $54^{\circ} 34^{\prime}$ & 284.0 \\
\hline Auto & Rondonópolis & $16^{\circ} 27^{\prime}$ & $54^{\circ} 34^{\prime}$ & 284.0 \\
\hline Auto & Salto do Céu & $15^{\circ} 08^{\prime}$ & $58^{\circ} 06^{\prime}$ & 303.0 \\
\hline Auto & $\begin{array}{c}\text { Santo Antônio do } \\
\text { Leste }\end{array}$ & $14^{\circ} 55^{\prime}$ & $53^{\circ} 53^{\prime}$ & 648.0 \\
\hline
\end{tabular}

Tabela 1. Continuation.

\begin{tabular}{|c|c|c|c|c|}
\hline Type & $\begin{array}{l}\text { Meteorological } \\
\text { stations }\end{array}$ & Latitude & Longitude & $\begin{array}{l}\text { Altitude } \\
\text { (m) }\end{array}$ \\
\hline Conv & $\begin{array}{l}\text { Santo Antônio do } \\
\text { Leverger }\end{array}$ & $15^{\circ} 78^{\prime}$ & $56^{\circ} 06^{\prime}$ & 140.0 \\
\hline Auto & $\begin{array}{l}\text { São Félix do } \\
\text { Araguaia }\end{array}$ & $11^{\circ} 37^{\prime}$ & $50^{\circ} 43^{\prime}$ & 218.0 \\
\hline Conv & $\begin{array}{c}\text { São José do Rio } \\
\text { Claro }\end{array}$ & $13^{\circ} 27^{\prime}$ & $56^{\circ} 39^{\prime}$ & 350.0 \\
\hline Auto & $\begin{array}{l}\text { São José do Rio } \\
\text { Claro }\end{array}$ & $13^{\circ} 27^{\prime}$ & $56^{\circ} 39^{\prime}$ & 350.0 \\
\hline Auto & Sinop & $11^{\circ} 58^{\prime}$ & $55^{\circ} 33^{\prime}$ & 371.0 \\
\hline Auto & Sorriso & $12^{\circ} 33^{\prime}$ & $55^{\circ} 43^{\prime}$ & 380.0 \\
\hline Auto & $\begin{array}{l}\text { Tangará da } \\
\quad \text { Serra }\end{array}$ & $14^{\circ} 39^{\prime}$ & $57^{\circ} 25^{\prime}$ & 321.5 \\
\hline Auto & Vila Bela & $15^{\circ} 03^{\prime}$ & $59^{\circ} 52^{\prime}$ & 222.0 \\
\hline \multicolumn{5}{|c|}{$\begin{array}{l}\text { Auto-Automated station. } \\
\text { Conv-Conventional station. }\end{array}$} \\
\hline & RMSE $=$ & \multicolumn{2}{|c|}{$\sum_{\mathrm{i}=1}^{\mathrm{n}}(\text { Yobs }- \text { Yest })^{2}$} & (3) \\
\hline
\end{tabular}

Where: RMSE is the root mean square error, Yobs the observed value, Yest the estimated value, and $n$ the total number of pairs of observed and estimated values.

The agreement refers to how accurate, or close to the real data, the estimated values are. To mathematically quantify such approximation, Willmott (1982) proposed a coefficient $(D)$, which ranges from zero to 1 , representing none to full agreement, respectively. This index is given by equation 4 .

$$
\begin{gathered}
\mathrm{D}=1-\frac{\sum_{1=1}^{\mathrm{n}}(\text { Yest }- \text { Yobs })^{2}}{\sum_{\mathrm{i}=1}^{\mathrm{n}}(\mid \text { Yest }-\overline{\mathrm{Y}}|+| \text { Yobs }-\overline{\mathrm{Y}} \mid)^{2}} \\
\mathrm{NS}=1-\frac{\sum_{\mathrm{i}=1}^{\mathrm{n}}(\text { Yobs }- \text { Yest })^{2}}{\sum_{\mathrm{i}=1}^{\mathrm{n}}(\text { Yobs }-\overline{\mathrm{Y}})^{2}}
\end{gathered}
$$

Where: $D$ is the agreement index, $\bar{Y}$ is the mean of the observed values, and NS corresponds to the Nash-Sutcliffe coefficient.

The accuracy was assessed by the correlation coefficient $(r)$. It indicates the degree to which data scatter from a linear regression model. In this case, measured and estimated temperature values were considered (Biudes et al., 2008).

The confidence index (equation 6) uses both coefficients ( $r$ and $D$ ). If its value equals zero, the confidence is null; if it equals 1, there is a total match (Camargo and Camargo, 2000). 


$$
\mathrm{C}=\mathrm{r} \times \mathrm{D}
$$

Where $C$ is the confidence index, $r$ is the correlation coefficient, and $D$ is the agreement index.

The criterion adopted to interpret the confidence index $(C)$, specifically for the average monthly temperature values, was that of Camargo and Sentelhas (1997), displayed in Table 2.

The definition of regions of either high or low climatic risk was associated with the incidence of the average temperatures during the soybean maturation (from January to February). During this phase, the physiological potential is considered to be at its highest. Both the altitude of the site and the sowing moment of the early cultivars were also taken into account. The following three categories were sorted according to temperature intervals: favorable $\left(\leq 24{ }^{\circ} \mathrm{C}\right)$, moderately favorable $\left(24.1\right.$ to $\left.25^{\circ} \mathrm{C}\right)$, and slightly favorable $\left(\geq 25.1^{\circ} \mathrm{C}\right)$.

After evaluating the efficiency of the models, the thematic maps were elaborated. In the creation process, map usage and geographical data compilation, interpolations were done through the inverse square distance method, in order to obtain the spatialization (Mello et al., 2003). The geographical information system ArcGIS was used to draw the map representing the best regions in Mato Grosso for producing seeds of early soybean cultivars.

\section{Results and Discussion}

In January and February, the minimum average temperatures were $22.5^{\circ} \mathrm{C}$ and $22.6{ }^{\circ} \mathrm{C}$, respectively; whereas the maximum average temperatures were $27{ }^{\circ} \mathrm{C}$ and $26.8^{\circ} \mathrm{C}$ (Table 3). All these observed values were close to the corresponding average temperature estimated for these months.

Overall, the estimates obtained by the model were very close to the observed data (Table 3). Both the Nash-Sutcliffe efficiency coefficient (NS) and the agreement index $(D)$ neared 1 , implying that the estimated temperature numbers

Table 2. Interpretation criterion for the performance of temperature, assessed by the confidence index $(C)$, as suggested by Camargo and Sentelhas (1997).

\begin{tabular}{cc}
\hline C value & Performance \\
\hline$>0.85$ & Excellent \\
$0.76-0.85$ & Very good \\
$0.66-0.75$ & Good \\
$0.61-0.65$ & Average \\
$0.51-0.60$ & Passable \\
$0.41-0.50$ & Bad \\
$\leq 0.40$ & Very bad
\end{tabular}

Table 3. Average observed (Tobs) and estimated (Test) temperatures $\left({ }^{\circ} \mathrm{C}\right)$ at the meteorological stations located in the state of Mato Grosso, from 2007 to 2014.

\begin{tabular}{|c|c|c|c|c|}
\hline \multirow{2}{*}{$\begin{array}{l}\text { Meteorologial } \\
\text { station }\end{array}$} & \multicolumn{2}{|c|}{ January } & \multicolumn{2}{|c|}{ February } \\
\hline & Tobs & Test & Tobs & Test \\
\hline Alta Floresta & 24.92 & 24.83 & 24.80 & 24.63 \\
\hline Alto Araguaia & 22.93 & 23.14 & 23.13 & 23.03 \\
\hline Alto Taquari & 22.47 & 22.42 & 22.59 & 22.37 \\
\hline Apiacás & 25.91 & 25.19 & 26.28 & 25.03 \\
\hline Brasnorte & 23.80 & 24.31 & 24.00 & 24.29 \\
\hline Cáceres & 26.90 & 26.80 & 26.10 & 26.59 \\
\hline Cáceres (Conv.) & 27.09 & 26.80 & 26.96 & 26.59 \\
\hline Campo Novo & 24.28 & 23.64 & 24.03 & 23.67 \\
\hline Campo Verde & 22.89 & 22.83 & 23.03 & 22.81 \\
\hline Canarana & 25.28 & 24.60 & 24.90 & 24.28 \\
\hline Carlinda & 24.78 & 24.85 & 24.93 & 24.64 \\
\hline Comodoro & 23.11 & 23.46 & 22.94 & 23.60 \\
\hline Cotriguaçú & 24.88 & 24.97 & 24.67 & 24.88 \\
\hline Cuiabá (Conv.) & 26.93 & 26.55 & 26.98 & 26.27 \\
\hline Cuiabá & 26.74 & 26.55 & 26.70 & 26.27 \\
\hline Diamantino & 25.87 & 25.47 & 25.80 & 25.29 \\
\hline Gaúcha do Norte & 25.05 & 24.82 & 25.63 & 24.51 \\
\hline Guaratã do Norte & 25.33 & 24.67 & 25.08 & 24.43 \\
\hline Gleba Celeste & 25.62 & 24.45 & 25.75 & 24.28 \\
\hline Guiratinga & 25.12 & 24.36 & 25.11 & 24.16 \\
\hline Itiquira & 24.08 & 24.11 & 24.20 & 23.97 \\
\hline Juara & 25.29 & 25.20 & 25.17 & 25.06 \\
\hline Juína & 24.56 & 25.57 & 24.46 & 25.45 \\
\hline Matupá & 25.04 & 24.95 & 24.94 & 24.72 \\
\hline Nova Ubiratã & 23.90 & 23.96 & 24.40 & 23.80 \\
\hline Novo Mundo & 24.12 & 24.31 & 24.18 & 24.29 \\
\hline Paranatinga & 24.24 & 24.40 & 24.24 & 24.18 \\
\hline Pontes Lacerda & 25.65 & 25.79 & 25.24 & 25.73 \\
\hline Porto Estrela & 26.40 & 26.53 & 26.20 & 26.31 \\
\hline Poxoréo & 25.55 & 24.83 & 25.48 & 24.63 \\
\hline Querência & 24.50 & 24.73 & 24.70 & 24.38 \\
\hline $\begin{array}{l}\text { Rondonópolis } \\
\text { (Conv.) }\end{array}$ & 25.77 & 25.87 & 25.77 & 25.59 \\
\hline Rondonópolis & 25.57 & 25.87 & 25.59 & 25.59 \\
\hline Salto do Céu & 25.40 & 25.50 & 25.03 & 25.40 \\
\hline $\begin{array}{c}\text { Santo Antônio do } \\
\text { Leste }\end{array}$ & 23.45 & 23.39 & 23.68 & 23.26 \\
\hline $\begin{array}{c}\text { Santo Antônio do } \\
\text { Leverger }\end{array}$ & 26.84 & 26.72 & 26.74 & 26.44 \\
\hline
\end{tabular}


Table 3. Continuation

\begin{tabular}{ccccc}
\hline \multirow{2}{*}{$\begin{array}{c}\text { Meteorologial } \\
\text { station }\end{array}$} & \multicolumn{2}{c}{ January } & \multicolumn{2}{c}{ February } \\
\cline { 2 - 5 } & Tobs & Test & Tobs & Test \\
\hline $\begin{array}{c}\text { São Félix do } \\
\text { Araguaia }\end{array}$ & 25.82 & 25.63 & 25.98 & 25.11 \\
São José do Rio & 24.84 & 24.98 & 25.04 & 24.84 \\
Claro (Conv.) & & & & \\
São José do Rio & 25.77 & 24.98 & 24.97 & 24.84 \\
Claro & & & & \\
Sinop & 24.43 & 24.65 & 24.69 & 24.46 \\
Sorriso & 24.73 & 24.67 & 25.10 & 24.50 \\
Tangará da Serra & 24.65 & 25.32 & 24.40 & 25.20 \\
Vila Bela & 25.77 & 25.96 & 25.0 & 25.91 \\
\hline RMSE & \multicolumn{2}{c}{0.42} & \multicolumn{2}{c}{0.57} \\
NS & \multicolumn{2}{c}{0.70} \\
D & \multicolumn{2}{c}{0.86} & \multicolumn{2}{c}{0.84} \\
$r$ & 0.93 & \multicolumn{2}{c}{0.83} \\
C & 0.99 & 0.83 \\
\hline
\end{tabular}

$\overline{R M S E-\text { root mean square error; } N S \text {-Nash-Sutcliffe efficiency coefficient; } D \text { - }}$ agreement index; $r$-correlation coefficient; $C$-confidence index.

were good enough, and that the model is therefore efficient. The correlation coefficient $(r)$ found for both observed and expected values were also close to 1 , indicating that there was a significantly strong positive correlation between the variables in January, and a strong positive one in February.

Table 3 also lists the confidence indices $(C)$ obtained for January (0.92) and February (0.83), which respectively represented a great and very good confidence levels. Hence, the estimated data have reliable applicability, according to the criteria proposed by Camargo and Sentelhas (1997) (Table 2).

It is worth noticing that the methods currently employed in Brazil for temperature modeling have been developed and used for quite some time. They have already proved to be efficient when it comes to specific localities, such as the state of Mato Grosso, where not enough data are available (Buriol et al., 1973; Sandanielo, 1987; Lima and Ribeiro, 1998; Abreu et al., 2011).

Since the coefficients satisfactorily endorsed the estimates of average temperature data, it became possible to elaborate the thematic maps of Mato Grosso, considering January (Figure 1A) and February (Figure 1B).

The zones deemed favorable (areas in green, Figure 1A) for the production of seeds of early soybean cultivars, considering maturation and harvest phases to taking place in January, are concentrated in both the Southeast and West of the state. Another favorable area was identified in the Central-South zone, including the proximities of the cities of Tangará da Serra and Diamantino, as well as some small locations bordering the
Southeastern region. In a less extent, other favorable sites were found in the Middle-North (Santa Rita do Trivelato, Nobres and Nova Ubiratã), Northwest (small areas in Aripuanã, Juara and Juina), Northeast (Santa Teresinha and Vila Rica), and North (Guarantã do Norte, Novo Mundo, Matupá, Terra Nova do Norte, Santa Helena and Marcelândia) (Figure 1A).

Similar profiles of favorable areas with temperatures below $24{ }^{\circ} \mathrm{C}$ were noticed in both months assessed. Nonetheless, in February, there was an enlargement of the zones considered favorable and moderately favorable in the Southeast, Middle-North, North, and Northeast of the state (Figure 1B). In the Southeastern region particular case, over $50 \%$ of the territory was sorted as favorable for producing seeds of early soybean cultivars. The exceptions were the town of Araguaiana, in the vicinities of Barra do Garças, and locations near Rondonópolis, Juscimeira, and Pedra Preta.

The areas in the Middle-North and North of Mato Grosso were almost entirely regarded as moderately favorable for the production of soybean seeds, with temperatures between 24.1 and $25^{\circ} \mathrm{C}$ (Figures 1A and 1B). The Northeast and Northwest of the state also presented zones with the same classification. Likewise, moderately favorable sites were found in the Southeast, namely in the cities of Paranatinga, Itiquira, and Barra do Garças, and also in the West, in Comodoro and North of Sapezal.

The Central-South regions (Figures 1A and 1B) showed the largest area considered slightly favorable for producing seed of early soybean cultivars. Within this region are the municipalities of Nobre, Tangará da Serra, Diamantino and Nortelândia.

Studies carried out in the states of Minas Gerais, Paraná, and Goiás pointed to different temperature classes. In the former, the agroclimatic zoning for production of high-quality soybean seeds defined regions with high and low climatic risk, by associating it with the average temperatures during the phases of maturation (when the physiological potential is at its maximum) and the altitude of the sites (Pádua et al., 2014). Considering the regular sowing season and having the maturation final stages and harvest happening in March, the authors established the following three classes of regions: favorable (average temperature equal to or below $23.5^{\circ} \mathrm{C}$ ); moderately favorable (average temperature ranging from 23.6 to $24.9^{\circ} \mathrm{C}$ ); and slightly favorable (average temperature above $25^{\circ} \mathrm{C}$ ).

In the state of Paraná, the areas were classified in T1 (average temperature above $24{ }^{\circ} \mathrm{C}$ ), T2 (average temperature between 22 and $24^{\circ} \mathrm{C}$ ), and T3 (average temperature below 22 $\left.{ }^{\circ} \mathrm{C}\right)$. In this zoning study, the authors verified that the best areas to produce soybean seeds coincided with mild temperatures (below $22{ }^{\circ} \mathrm{C}$ ) during the maturation phase. This ambient condition benefits the production of seeds with superior 
physiological and sanitary qualities (Costa et al., 1994).

In the state of Goiás, the zoning was altimetric (FrançaNeto et al., 2016). In this case, areas between 850 and 1189 $\mathrm{m}$ high were deemed the most favorable; whereas those from 700 to $849 \mathrm{~m}$ were considered favorable for soybean seed production.
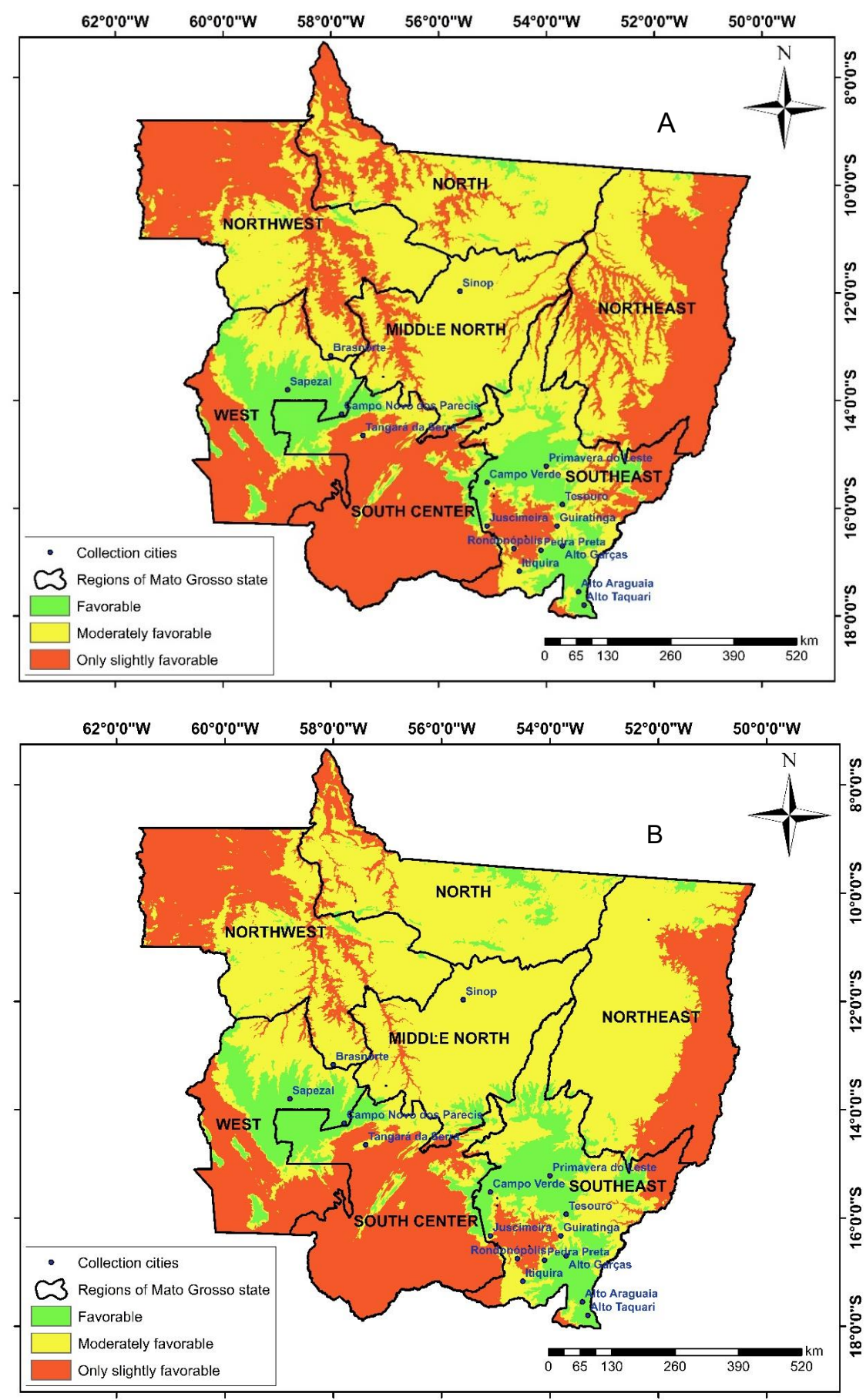

Figure 1. Agroclimatic zoning of the state of Mato Grosso for the production of seeds of early soybean cultivars [Glycine max L. Merrill] in January (A) and February (B). Favorable $\left(\leq 24{ }^{\circ} \mathrm{C}\right)$, moderately favorable $\left(24.1-25^{\circ} \mathrm{C}\right)$, and slightly favorable $\left(\geq 25.1^{\circ} \mathrm{C}\right)$. 


\section{Conclusions}

The majority of Southeast and West regions of Mato Grosso state are classified as favorable (average temperature $\leq 24{ }^{\circ} \mathrm{C}$ ) for producing seeds of early soybean cultivars.

\section{Acknowledgment}

The authors express their gratitude to Coordenação de Aperfeiçoamento de Pessoal de Nivel Superior - CAPES, for the doctorate scholarship granted to the first author; and also to Associação dos Produtores de Soja do Estado de Mato Grosso - APROSOJA/MT, and Fundo de Apoio a Cultura da Soja-FACS, for granting the financial support that made this research feasible.

\section{References}

ABREU, P.G.; ABREU, V.M.V.; FRANCISCON, L.; COLDEBELLA, A.; AMARAL, A.G. Estimativa da temperatura de globo negro a partir da temperatura de bulbo seco. Engenharia na Agricultura, v.19, n.6, 2011. http://www.seer.ufv.br/seer/index.php/reveng/article/ view/273/196

BIUDES, M.S.; VALENTINI, C.M.A.; CAMPELO JÚNIOR, J.H.; NOGUEIRA, J.S. Estimativa da evapotranspiração numa pastagem mista, em condições de cerrado, pelos métodos de razão de Bowen e Penman-Monteith. Ciência e Natura, v.30, n.1, p.71-86, 2008. https://periodicos.ufsm.br/cienciaenatura/article/view/9757

BRASIL. Ministério da Agricultura, Pecuária e Abastecimento. Zoneamento agrícola de risco climático. Brasília, 2012. http://www. agricultura.gov.br/politica-agricola/zoneamento-agricola/. Accessed on August 12 $2^{\text {th }}, 2015$.

BRASIL. Ministério da Agricultura, Pecuária e Abastecimento. Zoneamento Agrícola. Brasília, 2017. http://www.agricultura.gov. br/assuntos/riscos-seguro/risco-agropecuario/zoneamento-agricola. Accessed on March 19 $9^{\text {th }}, 2018$.

BURIOL, G.A.; ESTEFANEL, V.; FERREIRA, M.; PINTO, H.S. Estimativa das médias das temperaturas máximas mensais e anuais do Estado do Rio Grande do Sul. Revista do Centro de Ciências Rurais, v.3, n.1, p.131-150, 1973. http://www.scielo.br/pdf/rbeaa/ v14n6/a08v14n6

CAMARGO, A.P.; CAMARGO, M.B.P. Uma revisão analítica da evapotranspiração potencial. Bragantia, v.59, n.2, p.125-137, 2000. http://www.scielo.br/pdf/brag/v59n2/a02v59n2.pdf

CAMARGO, A.P.; SENTELHAS, P.C. Avaliação do desempenho de diferentes métodos de estimativa da evapotranspiração potencial no estado de São Paulo, Brasil. Revista Brasileira de Agrometeorologia, v.5, n.1, p.89-97, 1997. http://www.scielo.br/pdf/rbeaa/v11n6/ v11n06a06.pdf
CARGNELUTTI FILHO, A.; MALUF, J.R.T.; MATZENAUER, R. Coordenadas geográficas na estimativa das temperaturas máxima e média decendiais do ar no Estado do Rio Grande do Sul. Ciência Rural, v.38, n.9, p.2448-2456, 2008. http://www.scielo.br/pdf/cr/ v38n9/a05cr165.pdf

CARGNELUTTI FILHO, A.; MALUF, J.R.T.; MATZENAUER, R.; STOLZ, P.A. Altitude e coordenadas geográficas na estimativa da temperatura mínima média decendial do ar no Estado do Rio Grande do Sul. Pesquisa Agropecuária Brasileira, v.41, n.6, p.893-901, 2006. http://www.scielo.br/pdf/pab/v41n6/30852.pdf

COSTA, N.P.; PEREIRA, L.A.G.; FRANÇA-NETO, J.B.; HENNING, A.A.; KRZYZANOWSKI, F.C. Zoneamento ecológico do Estado do Paraná para produção de sementes de cultivares precoces de soja. Revista Brasileira de Sementes, v.16, n.1, p.1219, 1994. https://www.agencia.cnptia.embrapa.br/Repositorio/ abrates0001_000gelnlftf02wx5ok0ylax2lnkutb9x.pdf

FARIAS, J.R.B. Limitações climáticas à obtenção de rendimentos máximos de soja. In: CONGRESSO DE LA SOJA DEL MERCOSUR, 5, 2011, Argentina. Workshops. Londrina: EMBRAPA SOJA, 2011. p.1-4. https://ainfo.cnptia.embrapa.br/digital/bitstream/ item/47554/1/farias.limitacoes.pdf

FORTI, V.A.; CÍCERO, S.M.; PINTO, T.L.F. Avaliação da evolução de danos por "umidade" e redução do vigor em sementes de soja, cultivar TMG113-RR, durante o armazenamento, utilizando imagens de raios X e testes de potencial fisiológico. Revista Brasileira de Sementes, v.33, n.3, p.123-133, 2010. http://www.scielo.br/pdf/rbs/ v32n3/v32n3a14.pdf

FRANÇA-NETO, J.B.; KRZYZANOWSKI, F.C.; HENNING, A.A.; PÁDUA, G.P.; LORINI, I.; HENNING, F.A. Tecnologia da produção de semente de soja de alta qualidade. Londrina: Embrapa Soja, 2016. 82p. (Embrapa Soja, Documentos, 380). https://ainfo. cnptia.embrapa.br/digital/bitstream/item/151223/1/Documentos380-OL1.pdf

INMET. Instituto Nacional de Meteorologia. Banco de Dados Meteorológicos para Ensino e Pesquisa. Dados Históricos. BRASÍLIA: INMET, 2015. http://www.inmet.gov.br/portal/index. php?r=bdmep/bdmep. Accessed on July $25^{\text {th }}, 2015$.

LIMA, M.G.; RIBEIRO, V.Q. Equações de estimativa da temperatura do ar para o estado do Piauí. Revista Brasileira de Agrometeorologia, v.6, n.2, p.221-227, 1998. http://www.sbagro. org.br/bibliotecavirtual/arquivos/184.pdf

MELLO, C.R.; LIMA, J.M.; SILVA, A.M.; MELLO, J.M.; OLIVEIRA, M.S. Krigagem e inverso do quadrado da distância para interpolação dos parâmetros da equação de chuvas intensas. Revista Brasileira de Ciência do Solo, v.27, n.5, p.925-933, 2003. http:// www.scielo.br/pdf/rbcs/v27n5/v27n5a17.pdf

MITIDIERI, F.J.; MEDEIROS, J.X. Zoneamento agrícola de risco climático: ferramenta de auxílio ao seguro rural. Revista de Política Agrícola, v.17, n.4, p.36-46, 2008. https://seer.sede.embrapa.br/ index.php/RPA/article/view/435 
PÁDUA, G.P.; FRANÇA-NETO, J.B.; ROSSI, R.F.; CÂNDIDO, H.G. Agroclimatic zoning of the state of Minas Gerais for the production of high quality soybean seeds. Journal of Seed Science, v.36, n.4, p.413-418, 2014. https://ainfo.cnptia.embrapa.br/digital/ bitstream/item/118346/1/Agroclimatic-zoning-of-the-state-ofMinas-Gerais-for-the-production.pdf

RODRIGUES, E.P.; RODRIGUES, N. Zoneamento Agrícola de Risco Climático completa 20 anos. Embrapa Trigo, Passo Fundo, 2016. https://www.embrapa.br/trigo/busca-de-noticias/-/ noticia/183227370/zoneamento-agricola-de-risco-climaticocompleta-20-anos. Accessed on March 19 ${ }^{\text {th }}, 2018$.

SANDANIELO, A. Estimativa das temperaturas médias mensais e anuais na área do programa PÓLO NOROESTE PDRIMT. Cuiabá: EMPAMT, 1987. 20p. (Boletim de Pesquisa, 3). https://www.bdpa.cnptia.embrapa.br/consulta/bus-

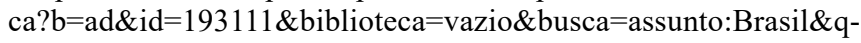
Facets $=$ assunto:Brasil \&sort $=\&$ paginacao $=$ t $\&$ paginaAtual $=945$
TARIFA, J.R. Mato Grosso: clima, análise e representação cartográfica. Cuiabá-MT: Entrelinhas, 2011. (Série recursos naturais e estudos ambientais). 102p.

WILLMOTT, C.J. Some comments on the evaluation of model performance. Bulletin American Meteorological Society, v.63, n.11, p.1309-1313, 1982. https://journals.ametsoc.org/doi/pdf/10.1175/15200477\%281982\%29063\%3C1309\%3ASCOTEO\%3E2.0.CO\%3B2

This is an Open Access article distributed under the terms of the Creative Commons Attribution License, which permits unrestricted use, distribution, and reproduction in any medium, provided the original work is properly cited. 